\title{
The South-West Essex Technical College and School of Art
}

\begin{abstract}
$\mathrm{W}$ HEN the historian of the future makes a survey of the development of education in Great Britain, he will undoubtedly consider the rapid advance in all forms of technical education as the characteristic feature of the present period. We who live in the period may perhaps be too near the gradual evolution to appreciate fully its magnitude and far-reaching effects. Yet, when one county, and that not a large nor highly industrial one, can, within a few years, erect two large technical colleges, only a few miles apart, each costing more than
\end{abstract}

The building is, in plan, shaped like the letter $\mathrm{E}$ and faces south. It covers an area of two and a quarter acres and is designed in the Georgian style, faced with multi-coloured bricks that contrast with the rusticated plinth, cornice and window dressings. It contains four floors, and the main entrance, placed at the top of a bold flight of steps, is rendered beautifully conspicuous by its portico of artificial stone supported by six Corinthian columns and surrounded by a pediment. The west wing, forming the upper prong of the $\mathbf{E}$, is occupied by the departments of

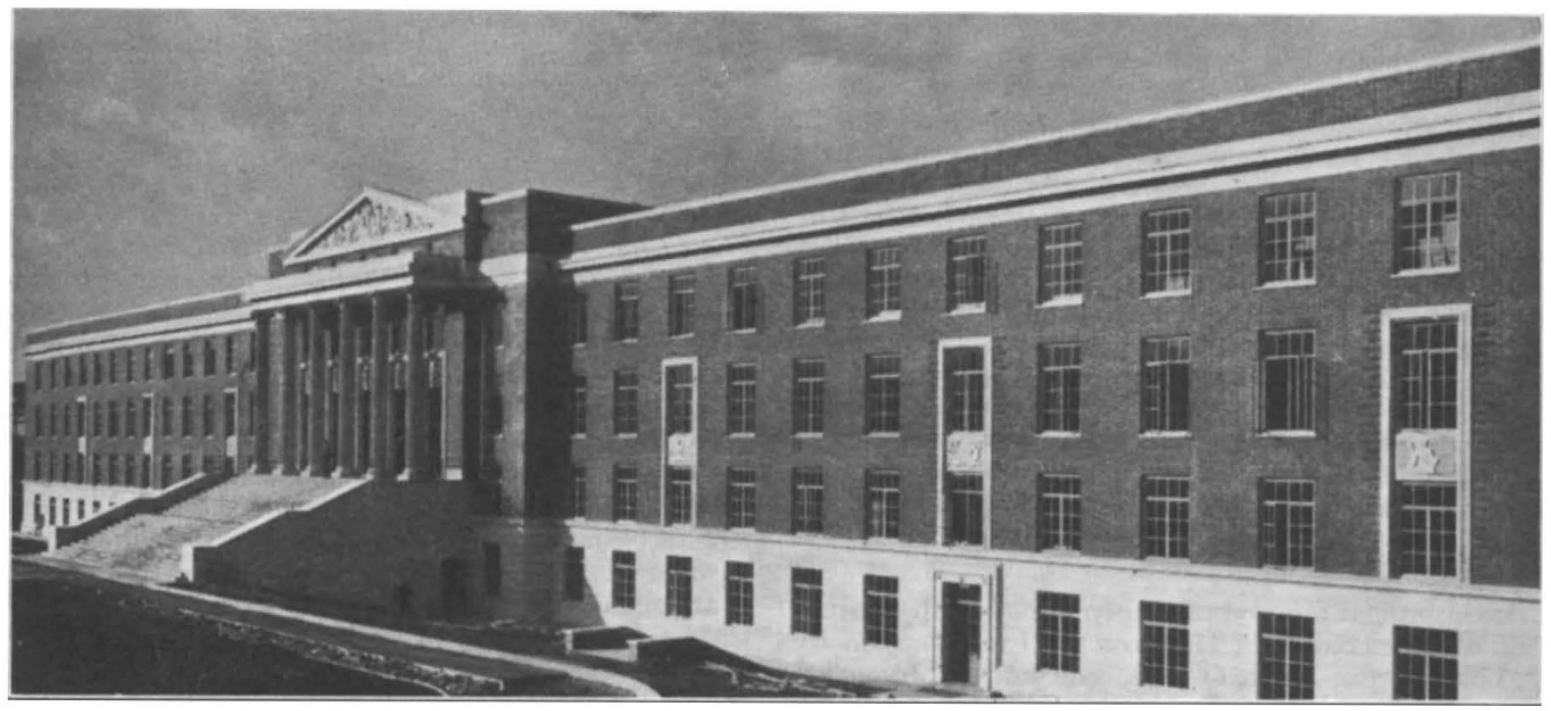

$£ 200,000$ and accommodating 6,000 evening and 1,100 day students, there can be no doubt that this mechanized age has forced the pace of technical education very considerably.

The increased demand for more adequate facilities for practical education, together with the rapid development of many suburban districts due to the migration of the population, led the Essex Education Authority in 1933 to devise a regional scheme. The county was divided into four regions having centres at Colchester, Chelmsford, Dagenham and Walthamstow. Technical schools were already in existence in several districts, but to meet modern requirements, it was decided to enlarge and re-equip those at Colchester and Chelmsford and to erect entirely new buildings at Dagenham and Walthamstow. The South-Fast Essex Technical College, situated on spacious grounds on the south side of Longbridge Road about two miles from Barking station, was officially opened in 1936 and a brief account of this huge college appeared in NATURE of March 27, 1937. The fourth region is served by the South-West Essex Technical College and School of Art, situated on a large site in Forest Road, Walthamstow. This magnificent edifice was opened on February 28, 1939, by the Right Hon. The Earl de la Warr, president of the Board of Education. It is designed to serve the Boroughs of Walthamstow, Leyton, Chingford and Wanstead and Woodford together with the smaller districts of Waltham, Epping and Ongar. science, commerce, domestic science and building, with a well-equipped gymnasium at the north end. In the east wing are to be found the School of Art and, at the northern extremity, a second gymnasium. Between the two gymnasia, provision in the form of a separate one-story building has been made for the engineering workshops. The central prong of the $\mathrm{E}$ actually forms the main axis of the College and contains the large and spacious assembly hall on the ground floor with the swimming bath below in the basement, and above, the library on the first floor with a refectory and kitchens on the second floor. The great hall, $100 \mathrm{ft}$. long, $55 \mathrm{ft}$. wide and $22 \mathrm{ft}$. high, will seat more than one thousand people and is provided, at the north end, with a stage $20 \mathrm{ft}$. deep completely equipped for modern dramatic and operatic productions. The swimming pool, fitted with springboards, diving stage, changing and shower rooms, is $100 \mathrm{ft}$. by $42 \mathrm{ft}$. and is illuminated by specially devised ceiling lights.

The frontage block - the vertical stroke of the Econtains staff rooms in the basement; chemical and physical laboratories, with storage and lecture rooms on the lower ground floor ; administrative offices, board-room, etc., on the ground floor, and above, on the top floor, special rooms for bookkeeping, commodities and retail trades. One special room should be noted in this block. On the ground floor nearly opposite the board-room is the nursery where mothers may leave their children in the care of a trained nurse 
while they are attending classes! The corridor floors are covered with grey mottled rubber to render the movement of students as silent as possible, and supplementary to the main staircases, passenger lifts have been installed.

It was John Ruskin who wrote, many years ago, "The entire object of true education is to make people not merely do the right things but enjoy the right things". Yet, the pioneers of technical education were mainly concerned with providing a training which was severely utilitarian. But, as Dr. H. Lowery, the principal of the College, aptly points out, "A now problem . . . has arisen-it becomes necessary to provide training for leisure as well as for vocation". Here then is a new function implying heavy responsibilities for the modern college. It is essential to recognize and to cater for the proper use of leisure, and here, in this magnificent new institution, ample opportunities are afforded for developing the true recreational and communal spirit. To quote
Dr. Lowery again, "it is our desire that the College shall become one great educational and recreational community centre where men and women may meet in their leisure time for the purpose of engaging in matters of common interest, thereby securing the fullest opportunity for self-expression".

The material building of this huge college has been very efficiently carried out by the general contractors, Messrs. F. R. Hipperson and Son, Ltd., of London, to the plans of Mr. J. Stuart, the architect, but an even greater work will now be undertaken by the principal and his large staff in laying the foundations of another edifice which will undoubtedly reveal itself in the trained mind, skilled craftsmanship, cultured recreation and, what is most important of all, trustworthiness and reliability of character. As R. W. Dale once wrote: "The immediately possible is hardly worth living for. It is the ideal that kindles enthusiasm and gives inspiration and vigour to all human effort".
F. G. W. B.

\section{Peneplains and Related Land Forms}

$I^{\mathrm{T}}$ is now nearly fifty years since W. M. Davis introduced the term 'peneplain' for the surface of low relief which might be expected to mark the end-stages of a long period of sub-aerial erosion under stable conditions. The term was received with a certain suspicion and lack of cordiality among British workers and it has been used comparatively little in their writings. Geographers and geomorphologists will therefore note with interest that the Geological Society recently discussed some of the questions at issue.

In introducing the subject, Dr. F. Dixey's main contention was that the term 'peneplain' is properly applicable to local areas which, though extensive, are far from being of continental dimensions. The common presentation of a cycle of erosion as running its course in a region of homogeneous rocks and resulting ultimately in the base-levelling of a whole land mass leads, in his view, to an unwarrantable attempt to limit the application of the term peneplain. He directed attention to the "two-peneplain topography" described by A. D. Coombe in Uganda, and common indeed throughout Africa, and he showed that such conditions must inevitably arise where weak and resistant rock-masses are juxtaposed. The lower surface opened out in weaker rocks, such, for example, as infaulted strips of Karroo sediments, may have the characteristics of a true peneplain, even though locally interrupted by residual masses and abutting elsewhere against steep slopes. Thus there arose veritable flights of peneplains as between the northern end of the Nyasa rift and the Luangwa valley. Here the following erosion surfaces are distinguishable: a late Jurassic surface at about 7,000 ft., a late Cretaceous or Early Tertiary surface at 5,000 ft., a Miocene surface at 4,000 ft., and a late Tertiary surface developed at about 3,000 ft. on friable Cretaceous rocks in local troughs. Further, a sub-Cretaceous surface has been exhumed locally by erosion and stands at about 2,000 ft. This surface and the late Tertiary surface rank as local peneplains in Dr. Dixey's sense, though others have denied them such rank because they are enclosed by highland areas.

Most other contributors to the discussion expressed agreement with Dr. Dixey, and Mr. J. M. Edmonds described somewhat comparable conditions in the Anglo-Egyptian Sudan. Dr. K. C. Dunham, however, noted that the Rio Grande and the Gila River are flanked by erosion surfaces, up to 80 miles long and 30 miles wide, produced by lateral corrasion. These would apparently rank as local peneplains in Dixey's scheme, but he thought this constituted an extension of the term peneplain and one unlikely to prove acceptable to American workers.

The discussion ranged widely over other cognate matters and several points of view were represented. Prof. O. T. Jones deplored the lack of any agreed definition of the features of a peneplain. He maintained that, in one sense, the whole of England and most of Wales is a peneplain rising gently from sealevel to more than $2,000 \mathrm{ft}$., and truncating all formations from the Pre-Cambrian to the Pliocene. Despite the considerable relief of parts of this surface, such relief can scarcely amount to 10 per cent of the thickness of strata removed by erosion. He also emphasized the probable importance of wind erosion in producing extensive surfaces of low relief.

Other speakers were, by implication at least, unwilling to accept so wide and general a connotation for the term 'peneplain'. Dr. Hollingworth pointed out that Davis's conception of a single peneplain in the Appalachian region is now challenged by several alternative and mutually inconsistent interpretations, most of which agree, at least, in representing the surface as complex and composite. Similarly, Mr. J. F. N. Green expressed the belief that many surfaces in the south of England which might be regarded as peneplains on general inspection have proved susceptible of dissection into distinct terrace-like features, separated by bluffs. Mr. A. A. Miller and Dr. S. W. Wooldridge raised a further issue in pointing out that many of the 'high-level platforms' of Britain, as well as most of the 'fossil' surfaces, 